Portland State University

PDXScholar

Environmental Science and Management

Faculty Publications and Presentations

2008

\title{
Invasive Predator, Bythotrephes, has Varied Effects on Ecosystem Function in Freshwater Lakes
}

Angela L. Strecker

Portland State University, angela.strecker@wwu.edu

Shelley E. Arnott

Queen's University - Kingston, Ontario

Follow this and additional works at: https://pdxscholar.library.pdx.edu/esm_fac

Part of the Environmental Sciences Commons, and the Terrestrial and Aquatic Ecology Commons Let us know how access to this document benefits you.

\section{Citation Details}

Strecker, Angela L. and Arnott, Shelley E., "Invasive Predator, Bythotrephes, has Varied Effects on Ecosystem Function in Freshwater Lakes" (2008). Environmental Science and Management Faculty Publications and Presentations. 46.

https://pdxscholar.library.pdx.edu/esm_fac/46

This Post-Print is brought to you for free and open access. It has been accepted for inclusion in Environmental Science and Management Faculty Publications and Presentations by an authorized administrator of PDXScholar. Please contact us if we can make this document more accessible: pdxscholar@pdx.edu. 
1 RH: Invader effects on ecosystem function

2

3

4

5

6 Invasive predator, Bythotrephes, has varied effects on ecosystem function in

7 freshwater lakes

8

9

10 Angela L. Strecker ${ }^{1,2}$ and Shelley E. Arnott

11 Department of Biology, Queen's University, 116 Barrie St., Kingston, Ontario, Canada K7L 3N6

12

13 I'Corresponding author's email:astrecker@eeb.utoronto.ca

$14{ }^{2}$ Current address: Department of Ecology \& Evolutionary Biology, University of Toronto,

1525 Harbord St., Toronto, Ontario, Canada M5S $3 G 5$

16 Tel: (416) 946-7223

17 Fax: (416) 978-8532

18 
ABSTRACT

Bythotrephes longimanus is an invertebrate predator that has invaded the North American Great

21 Lakes and a number of inland lakes, where it preys on crustacean zooplankton. We examined the

22 effect of Bythotrephes on two measures of ecosystem function during a four month observational

23 study of freshwater lakes on the boreal shield. Bythotrephes-invaded lakes had significantly lower

24 epilimnetic zooplankton abundance and production compared to reference lakes. On average,

25 Bythotrephes consumed $34 \%$ of zooplankton production when it was present in lakes. There was

26 some evidence of changes in the timing of zooplankton production, as well as shifts to cooler, less

27 productive habitats, which may lessen the overall effect of the invader on the transfer of energy to

28 higher trophic levels. We experimentally demonstrated a weak trophic cascade where invader

29 predation reduced zooplankton biomass, and subsequently increased phytoplankton growth.

30 However, the response was small in magnitude and not biologically relevant at the whole lake-

31 scale. The most conspicuous effect of Bythotrephes that we measured was a diversion of energy

32 away from native predators at higher trophic levels.

33

34 Keywords: invasive species, ecosystem function, crustacean zooplankton, Bythotrephes,

35 freshwater lakes, secondary production, zooplankton grazing 
INTRODUCTION

The introduction of non-indigenous species is expected to be one of the greatest threats to

species across all ecosystems (Wilcove and others 1998; Sala and others 2000) and the single most important driver of biodiversity loss in freshwater lakes (Sala and others 2000). Although there is evidence that invasive species can alter ecosystem function (Brooks and others 2004; Zhu and others 2006), we currently lack understanding of how newly-introduced species may affect ecosystem processes (Millenium Ecosystem Assessment 2005). Thus, the invasion of a nonnative species presents a unique opportunity to understand how complex ecosystems operate. Bythotrephes longimanus (Crustacea, Branchiopoda, Onychopoda) is a parthenogenetic invertebrate predator that has invaded all of the North American Great Lakes (Jin and Sprules 1990), and > 100 inland lakes in North America, including waterbodies in Ontario (N. Yan, unpublished data), Minnesota (Branstrator and others 2006), and Michigan (Jarnagin and others 2000). Although studies have indicated that Bythotrephes prefers large, deep, low productivity lakes in both its native Eurasia and in invaded regions (MacIsaac and others 2000), it has been found in smaller shallow waterbodies and higher productivity lakes as well (Jarnagin and others 2000). Bythotrephes has the potential to invade many boreal shield and northern temperate lakes, especially those visited by human vectors.

Bythotrephes can have substantial effects on the community structure of its primary prey, crustacean zooplankton, and although there is some degree of among-lake variability in the response to invasion, the general trend has been reductions in species richness (Yan and others 2002; Strecker and others 2006), total community biomass (Boudreau and Yan 2003; Strecker and Arnott 2005), and total community abundance of zooplankton (Yan and others 2001; Strecker and 
zooplankton richness and abundance (Yan and others 2001; Boudreau and Yan 2003; Strecker and others 2006).

Zooplankton are a central component in freshwater food webs, transferring energy to young-of-year (YOY) and planktivorous fish via production of biomass, grazing on phytoplankton biomass, and recycling dissolved nutrients to phytoplankton. Foraging success of juvenile fish can be greatly influenced by variability in zooplankton populations in freshwater ecosystems (Chick and van den Avyle 1999; Beauchamp and others 2004). In one study, it was observed that Bythotrephes consumed large portions of zooplankton production in Harp Lake, Ontario during summer (Dumitru and others 2001), potentially decreasing the amount of production available to other components of the aquatic food web. Additionally, when Bythotrephes was present, total consumption of the invertebrate predator guild increased by $>300 \%$ (S. Foster, pers. comm.), potentially reducing the efficiency of energy transfer to higher trophic levels (Sprules 1980). The impact of zooplankton on phytoplankton is influenced by zooplankton biomass and community composition - and is therefore potentially affected by Bythotrephes predation.

Zooplankton grazing and nutrient recycling can have a greater effect on phytoplankton biomass in lakes than nutrient recycling of fish (Sarnelle and Knapp 2005), and grazing by large cladoceran zooplankton can exert strong top-down control on phytoplankton (Elser and Goldman 1991). Thus, zooplankton community structure in lakes can be a primary determinant of the flow of energy and nutrients to all trophic levels; however, few studies have examined the effects of invaders on nutrient and energy flow at multiple levels of organization in freshwater systems (Simon and Townsend 2003).

The overall purpose of this study was to determine the effects of the invasive predator, Bythotrephes, on ecosystem function in boreal lakes. Ecosystem function is commonly measured as changes in rates of productivity, decomposition, nutrient cycling, and resistance and resilience 
to perturbations (Loreau and others 2001). In our study we measured ecosystem function as changes in rates of secondary productivity and the combined effects of zooplankton grazing and nutrient cycling on phytoplankton. The two main objectives of our study were to examine: (1) the effect of Bythotrephes on crustacean zooplankton production within each lake stratum and throughout the ice-free season; and (2) if zooplankton impact on phytoplankton is influenced by Bythotrephes-induced changes in community composition and biomass.

Based on reductions in zooplankton abundance observed in previous studies (Yan and others 2001; Strecker and others 2006), we hypothesized that Bythotrephes would negatively affect zooplankton production. Bythotrephes tends to be absent in lakes until middle-to-late June (Yan and others 2001), creating a window of opportunity before this time period for zooplankton to increase their reproduction. Therefore, we expect to see a less pronounced effect of Bythotrephes on coarse measures of overall seasonal and whole water column production, but differences in fine-scale temporal (biweekly) and spatial (variation between strata) patterns of zooplankton production. Secondly, the effects of zooplankton grazing and nutrient recycling on phytoplankton are significantly influenced by both community biomass and composition (Elser and Goldman 1991; Cyr 1998; Elser and others 2000), thus, we would expect zooplankton communities in invaded lakes to have a lessened impact on phytoplankton as a result of Bythotrephes-induced reductions in total zooplankton biomass and selective predation on cladocerans.

\section{MATERIALS AND METHODS}

\section{Study Site and Sampling}

Eight lakes in the Parry Sound and Muskoka districts of south-central Ontario were chosen for our study (Table 1). The study lakes are located in mixed-forest catchments, have low 
productivity (oligo-mesotrophic), and are circumneutral. Lakes are relatively deep, ranging from

108

109

110

111

112

113

114

115

116

117

118

119

120

121

122

123

124

125

126

127

128

130

$23-59 \mathrm{~m}$, and have surface areas ranging from $72-2058$ ha (Table 1). Lakes were chosen based on prior knowledge of the invasion of Bythotrephes (invaded lakes had Bythotrephes for at least 5 years), proximity, and similarity of chemical, physical, and morphometric characteristics. As well, all of the lakes contained the glacial relict Mysis relicta, which is indicative of a similar postglacial history, and planktivorous fish communities, including yellow perch (Perca flavescens) and a combination of cisco (Coregonus artedi), rainbow smelt (Osmerus mordax), and lake whitefish (Coregonus clupeaformis) (Appendix 1).

Lakes were visited every two weeks from May to September $2003(\mathrm{n}=9)$, and samples were generally taken within a five-day time period. At a deep station in the lake, temperature, dissolved oxygen, and Secchi depth were measured, and samples were taken for zooplankton, Bythotrephes, and chlorophyll $a(\mathrm{chl} a)$. Four additional sample stations for Bythotrephes collection were chosen along a transect, starting at the deep station and moving toward shore, marking each station with a GPS to locate it on the next sampling date (see Strecker and others 2006 for sampling details). Logistical constraints prevented sampling at night so all samples were taken during the day. Chl $a$ samples were taken from the epilimnion using a $2.5-\mathrm{cm}$ diameter integrated tube sampler. The integrated tube sampler was also used to collect water from the epilimnion on the week of 14 July 2003 for analysis of water chemistry variables.

Zooplankton were sampled with a $110-\mu \mathrm{m}$ mesh conical closing net that was $0.5 \mathrm{~m}$ in diameter. Samples were taken in the epilimnion, metalimnion, and hypolimnion (from $5 \mathrm{~m}$ off the lake bottom to the top of the hypolimnion) after thermal strata were determined from a temperature profile taken at 1-m intervals. The top of the metalimnion was defined as a change of $>1^{\circ} \mathrm{C}$ per meter, and the top of the hypolimnion by a change of $<0.2^{\circ} \mathrm{C}$ per meter. On the first sampling date, stratification had not yet been achieved in Bernard Lake, so the depth of the entire 
131 water column was roughly divided in 3 and samples were taken from those depths. Average

132 temperatures from each strata in Bernard Lake on the first date were consistent with other lakes,

133 thus, we do not believe that this method affected our results. The hypolimnion of Doe Lake could

134 not be sampled on seven dates because it was too shallow; therefore, this lake was excluded from

135 hypolimnetic abundance and production estimations. Samples for Bythotrephes were taken over

136 the entire water column, starting from $5 \mathrm{~m}$ off the lake bottom, using a $400-\mu \mathrm{m}$ mesh conical net

137 that was $0.5 \mathrm{~m}$ in diameter. Bythotrephes and zooplankton samples were anesthetized and

138 preserved in 5.5\% sugared and buffered formalin.

139 Zooplankton samples were enumerated and measured on a Leica MZ12.5 dissecting

140 microscope using the semi-automated counting system ZEBRA2 (Allen and others 1994).

141 Subsamples of a known volume were taken and a minimum of 350 individuals were identified to

142 genus, with the exception of Daphnia mendotae, Eubosmina (Neobosmina) tubicen, Eubosmina

143 (Eubosmina) coregoni, Eubosmina (Eubosmina) longispina, and other species which are the only

144 representative of their genus in the area. Diaptomid calanoid copepods belonging to the genera

145 Leptodiaptomus and Skistodiaptomus were grouped simply as Diaptomus spp. To obtain a

146 representative enumeration of all zooplankton genera present, only 40-50 individuals of the

147 dominant taxa, 40-50 copepodids per order, and 20-30 nauplii per order were counted. Both loose

148 and attached eggs were counted in the subsamples, stopping either when the minimum number of

149 individuals was reached or $>700$ loose eggs were counted. Loose eggs were designated as

150 cladoceran or copepod and apportioned to the number of adults present. Bythotrephes samples

151 containing $<32$ individuals were counted in their entirety, while samples with greater numbers

152 were split with a Folsom plankton splitter and mixed to ensure that clumping did not occur. All

153 instars were enumerated and abundances were averaged across the five sampling stations. 


\section{Zooplankton Production}

Although Bythotrephes (Pangle and Peacor 2006) and other visual predators (Lampert 1989) can induce diel vertical migration of zooplankton, we chose to sample during the day to specifically examine the vertical distribution of productivity available to visually foraging predators, such as cisco, which are daytime feeders (Milne and others 2005). Comparisons of day and night vertically-stratified samples of zooplankton taken in 2007 in most of our study lakes suggest that some zooplankton migrated downwards in invaded lakes during the day, while diel migrations in non-invaded lakes tended to be small in magnitude (S. Arnott, unpublished data). There was variability in the extent of migration in invaded lakes: on average $15 \%$ of total zooplankton (range: $-13-31 \%$; negative value represents migration in the opposite direction) moved from the metalimnion to the epilimnion at night, but migration of zooplankton away from the hypolimnion to warmer temperatures at night was small (mean: $9 \%$, range: $-9-28 \%$ ). We acknowledge that as a result of these migrations, our calculations may underestimate metalimnetic production in invaded lakes by including organisms that have spent nights at warmer temperatures. Biweekly zooplankton production was calculated using two methods. For the calanoid copepod species which do not carry their eggs in an egg sac (e.g., Senecella calanoides), the cohort method was used (Downing 1984). For all other zooplankton, the egg-ratio method was used (Borgmann and others 1984), following Paloheimo (1974). Temperature and species-specific values for egg development time were determined from the literature (see Kuns and Sprules 2000), and the mean temperature of each stratum was used. Mean dry weights for zooplankton were calculated using length-weight regressions (McCauley 1984; Culver and others 1985; Yan and Mackie 1987; Yan and Pawson 1997; W.G. Sprules, unpublished data). Areal biweekly production was calculated by multiplying volumetric production by the depth of the stratum. All of our production estimates were calculated at the genus level and then summed across all taxa to 
obtain total crustacean zooplankton production. Bythotrephes production was calculated separately from the crustacean zooplankton community, as we wanted to examine the effects of Bythotrephes as a predator on zooplankton productivity, exclusive of its contribution to total zooplankton productivity (for comparison, Bythotrephes production is displayed in Fig. 1).

Biweekly Bythotrephes consumption $\left(\mathrm{mg} \mathrm{m}^{-2}\right.$ fortnight ${ }^{-1}$ ) was estimated by dividing Bythotrephes biweekly production $\left(\mathrm{mg} \mathrm{m}^{-2}\right.$ fortnight $^{-1}$; calculated by the egg-ratio method from whole water column samples) by growth efficiency, which was estimated at $27 \%$ for a population of mixed instars (Dumitru and others 2001). Consumption by Bythotrephes was contrasted with zooplankton production from the epilimnion and metalimnion, as a concurrent study in a subset of the lakes in our study suggests that this is where the invader is generally found (Young and Yan 2008).

\section{Impact of Zooplankton on Phytoplankton}

To assess the effects of Bythotrephes on trophic interactions between zooplankton and phytoplankton, an in situ experiment was conducted three times in a subset of the study lakes: two invaded and three reference lakes. Using a technique modified from Elser and Goldman (1991), Cyr (1998), and Sommer and others (2001), we measured zooplankton impact on the phytoplankton community, including direct grazing effects, but also indirect effects, such as nutrient recycling, as no nutrients were added to the carboys. Four translucent 20-L carboys were deployed for $72 \mathrm{hr}$ in each lake, once during June, July, and August, approximately four weeks apart. Water was taken from the region of the lake at which the carboys were incubated $(\sim 50 \%$ light penetration), thus minimizing between-lake differences in light exposure. Water was filtered through $80-\mu \mathrm{m}$ mesh to remove zooplankton and added to each carboy. Zooplankton were added to each of the carboys at several densities $(0,1,2$, and $3 \times$ ambient $)$ by taking discrete hauls with a 
closing net through each of the strata (epi-, meta-, and hypolimnion), thus compensating for any

204 diel vertical migration that may have been occurring, but also likely overestimating grazing due to 205 the presence of hypolimnetic taxa that would not be feeding in the epilimnion during the day. The 206 carboys were then sealed, weighted, and incubated for $72 \mathrm{hr}$. All predaceous macroinvertebrates, 207 e.g., Bythotrephes, were excluded from the carboys. By removing Bythotrephes from the carboys, 208 we are thus explicitly testing how zooplankton communities shaped by invasion will influence 209 algal community biomass in short term experiments in invaded and reference lakes. Although 210 initial differences in the composition of phytoplankton communities could influence zooplankton 211 grazing, the invaded and reference lakes in this study have similar proportions of edible

212 phytoplankton cells (B. Beisner, unpublished data), suggesting that conditions were relatively 213 comparable in invaded and reference lakes. Chl $a$ samples from each carboy were taken at the 214 beginning and end of the experiment, concentrating water samples onto 1.2- $\mu \mathrm{m}$ glass fiber filters, 215 and measured using fluorometry. Following Cyr (1998), the realized algal growth rate per day for 216 the carboys that contain zooplankton $(r)$ were calculated from

$217 \quad(1) \quad r=\ln \left(C_{1} / C_{0}\right) / T$

218 where $C_{0}$ and $C_{1}$ are chl $a$ concentrations $\left(\mu \mathrm{g} \mathrm{L}^{-1}\right)$ at the beginning and end of the experiment, and $219 T$ is the length of time the experiment ran (days). Zooplankton impact was calculated as the slope 220 (b) of the equation (2) $\quad r=b(Z B)+a$

222 where $Z B$ is the zooplankton biomass at $0,1,2$ or $3 \times$ ambient biomass and $a$ is the growth rate in 223 the absence of zooplankton. Zooplankton biomass was determined from the average of the two 224 survey sampling dates that surrounded the experiment. The coefficients of the equation were estimated by linear regression. Percent change in algae (per day) was calculated as $\left(-\left(1-\mathrm{e}^{b}\right) \times\right.$ 100). Although this experiment and others upon which it was modeled (Elser and Goldman 1991; 
Cyr 1998) are brief, our experiment was designed to provide insight into possible trophic

228

229

230

231

232

233

234

235

236

237

238

239

240

241

242

243

interactions that may result from changes in lake food webs and should be looked upon as a simplified test of the interaction between zooplankton and phytoplankton without confounding factors from higher trophic levels.

\section{Statistical Analyses}

One-way ANOVAs were used to examine differences in physical, chemical, and morphological characteristics of study lakes. Repeated measures ANOVAs were used to test if there were differences between invaded and reference lakes for chl $a$, secondary production, zooplankton abundance, and egg ratio (eggs individual ${ }^{-1}$ ). Because of non-normality and heteroscedasticity in some of the above measures, all values were $\log (\mathrm{x}+1)$-transformed. The Huynh-Feldt adjusted $p$-value was used in situations where the assumption of sphericity was not met for repeated measures analyses. Although we would expect to observe seasonal changes in zooplankton communities, independent of invasion status, it was not our intention to describe these changes, therefore, we will not discuss time effect results unless there is an interaction with invasion. A two-factor ANOVA was used to test for differences in zooplankton grazing impact over all three experimental time periods in invaded and reference lakes, with time as a block factor. Statistical analyses were performed using Statistica 6.0 (StatSoft 2001).

\section{RESULTS}

\section{Zooplankton Production}

Reference and invaded lakes were similar in surface area, maximum depth, and primary productivity (chl $a$ and total phosphorus) (Table 1), as well as thermal structure (epilimnetic 
temperature: $\left.F_{1,6}=0.01, p=0.98\right)$. There was also no significant difference in concentrations of

251 calcium and dissolved organic carbon, $\mathrm{pH}$, and conductivity between lake categories (Table 1).

252 Zooplankton production was significantly lower in the epilimnion of Bythotrephes-invaded

253 lakes throughout the summer, declining on average by $>6000 \mathrm{mg} \mathrm{m}^{-2}$ season $^{-1}$, or about $67 \%$ (Fig.

254 2, Table 2). There was no difference in metalimnetic or hypolimnetic production between invaded

255 and reference lakes (Fig. 2, Table 2), although the hypolimnions of two of the four invaded lakes,

256 Bernard and Harp, were $18 \times$ and $13 \times$ more productive than the average hypolimnetic productivity

257 of reference lakes (Fig. 1). When all of the strata were combined, there was no statistical

258 difference in whole-water column zooplankton production between invaded and reference lakes

259 (Fig. 1, 2, Table 2).

In the epilimnion, production of calanoid copepods, cyclopoid copepods, and small

261 cladocerans was significantly reduced in Bythotrephes-invaded lakes (Fig. 3, Table 3).

262 Epilimnetic production by large cladocerans tended to be reduced in Bythotrephes-invaded lakes,

263 though not significantly. There was a significant Time $\times$ Invasion interaction for small

264 cladocerans, where production in invaded lakes was high early in the season, but declined

265 precipitously from an average of $442 \mathrm{mg} \mathrm{m}^{-2}$ fortnight ${ }^{-1}$ in May and early June to $<2 \mathrm{mg} \mathrm{m}^{-2}$

266 fortnight $^{-1}$ over the remainder of the sampling dates (Fig. 3, Table 3). In the metalimnion,

267 production by cyclopoids, calanoids, and small cladocerans was similar in reference and invaded

268 lakes, while large cladoceran production was 90\% lower in invaded lakes compared to reference

269 lakes, averaging $13 \mathrm{mg} \mathrm{m}^{-2}$ fortnight $^{-1}$ over the season (Fig. 3, Table 3). In the hypolimnion,

270 cyclopoid copepods had higher production in invaded lakes early in the season, followed by a

271 decrease beginning in mid-June, and calanoid copepod production was significantly greater in

272 invaded lakes (Fig. 3, Table 3). There was no difference in large and small cladoceran

273 hypolimnetic production between lake groups (Fig. 3, Table 3). 
The abundance of crustacean zooplankton in the epilimnion was significantly affected in

275 invaded lakes, with declines of $>33000$ individuals $\mathrm{m}^{-3}$, on average (Fig. 4, Table 2). There was 276 also a significant Time $\times$ Invasion interaction, such that abundances were similar in invaded and 277 reference lakes in May and early June, but showed significant declines in the invaded lakes after 278 this time. There was no difference between invaded and reference lake zooplankton abundance in 279 the metalimnion, hypolimnion, and when all strata are combined, nor were there any interactions 280 between invasion status and time (Fig. 4, Table 2).

281 Bythotrephes-invaded lakes had a marginally significant increase in numbers of eggs 282 produced per individual zooplankter in the hypolimnion, which was most noticeable early in the 283 summer (Fig. 5, Table 2). This peak was likely driven by extremely high egg production by 284 hypolimnetic cyclopoid copepods, who produced on average $>9000$ eggs $\mathrm{m}^{-3}$ (A. Strecker, 285 unpublished data), far greater numbers than other zooplankton of a similar size, and had greater numbers of eggs per individual in invaded lakes compared to reference lakes (Fig. 5, Table 4). When all strata were combined, there was a marginally significant increase in eggs produced per 288 individual zooplankter in invaded lakes compared to reference lakes on the first sampling date $\left(F_{1,6}=3.82, p=0.10\right)$. This early season peak in number of eggs per individual in invaded lakes 290 came mostly from small cladoceran and cyclopoid functional groups (Fig. 5). There was no 291 significant effect of invasion on total or functional group eggs per individual in the epilimnion, 292 metalimnion, or when all strata were combined, nor were there any significant Time $\times$ Invasion 293 interactions (Fig. 5, Table 2). Bythotrephes consumed substantial portions of the total seasonal zooplankton production 295 in three of the four invaded lakes (Fig. 6), on average consuming $>1000 \mathrm{mg} \mathrm{m}^{-2} \mathrm{season}^{-1}$ or about $29617 \%$ of secondary production from the middle of May to the middle of September. However, 297 Bythotrephes did not tend to appear until mid-June in our samples, thus zooplankton production 
consumed after Bythotrephes starts reproducing is, on average, about 34\% (Fig. 6). Bythotrephes consumed $>100 \%$ of zooplankton production on two sampling dates in Bernard Lake and Harp

300 Lake, but its consumption never exceeded zooplankton production in Peninsula and Vernon lakes.

301 In general, Bythotrephes production was low, only comprising $<6 \%$ of total zooplankton

302 production, on average (Fig. 1).

303

\section{Impact of Zooplankton on Phytoplankton}

In each grazing experiment, algae decreased in reference lakes and increased in invaded

lakes (Fig. 7a). There was a significant effect of invasion on zooplankton impact on the algal community (invasion: $F_{1,8}=23.13, p<0.01$, time: $F_{2,8}=0.85, p=0.46$ ), such that $\%$ change in in the long term, as changes in chl $a$ in the experimental carboys were typically $<1 \mu \mathrm{g} \mathrm{L}^{-1}$.

310 Indeed, there was no significant difference in epilimnetic chl $a$ concentrations between lakes with 311 and without Bythotrephes throughout the entire season in the entire subset of lakes sampled (Fig. $3127 \mathrm{~b}$, Table 1).

\section{DISCUSSION}

We found that the invasive invertebrate predator, Bythotrephes, altered some measures of ecosystem function in freshwater lakes, such as epilimnetic secondary production, but that other measures were generally unchanged. There was some evidence for seasonal shifts in the production of different functional groups and individual egg production in invaded lakes in May and early June, but this was not great enough to balance production lost to Bythotrephes consumption later in the season. The effects of Bythotrephes on whole lake productivity may be

321 moderated by behavioural shifts in zooplankton abundance to the cool dark waters of the 
322 hypolimnion and/or increased abundance of hypolimnetic species, and consequently, increased

323 production in the hypolimnion of some lakes. Bythotrephes cannot compensate for the declines in

324 biomass production observed in invaded lakes, as it generated $<6 \%$ of total zooplankton

325 production. Our study provides compelling evidence that Bythotrephes can alter the flow of

326 energy in parts of freshwater lakes, but may leave other measures of ecosystem function relatively

327 unaffected. Changes in energy flow will likely have implications for growth and reproduction of

328 other trophic levels in the food web, including macroinvertebrates, planktivorous fish, and young-

329 of-year piscivorous fish, since these organisms all rely on zooplankton as a major food source.

\section{Zooplankton Production}

There was a significant decrease in epilimnetic zooplankton production in lakes invaded by Bythotrephes. This was likely the result of significant reductions in zooplankton abundance in the epilimnion, as there was no difference in other factors that influence productivity, such as egg

335 production, chlorophyll $a$, and temperature, in invaded lakes compared to non-invaded lakes.

336 Although previous studies have observed declines in overall zooplankton abundance (Yan and 337 others 2001; Strecker and others 2006), this is the first study to detect negative effects of

338 Bythotrephes on epilimnetic zooplankton production in multiple lakes and reduced production in 339 several functional groups (calanoids, cyclopoids, and small cladocerans) within the epilimnion.

340 The substantial declines in epilimnetic production are likely the result of a combination of direct 341 predation on zooplankton by Bythotrephes, as well as behavioural shifts away from the epilimnion

342 to cooler darker habitat. Although we cannot determine the relative importance of predation 343 versus migration, what remains is that the epilimnion of lakes has dramatically changed following 344 the invasion of Bythotrephes, and that there is significantly less productivity available to foraging 345 species. Although few studies exist that compare secondary productivity across different 
346 predatory regimes, our results are similar in magnitude to those observed in a fish biomanipulation

347 experiment, where the introduction of piscivores into a piscivore-free lake resulted in reductions in 348 planktivorous fish, increased biomass of the native invertebrate predator Chaoborus, and

349 significant declines in zooplankton productivity (Ramcharan and others 2001). This suggests that

350 the introduction of non-native species can act in an analogous fashion to the complete restructuring

351 of a lake food web by the introduction of a top predator.

352 We observed an increase in productivity in the hypolimnion in some invaded lakes, which

353 likely results from predator-induced habitat shifts. As discussed above, diel vertical migrations of

354 zooplankton can confound estimations of secondary productivity. However, it is unlikely that

355 these migrations influenced our estimates of epilimnetic or hypolimnetic production because we

356 have no evidence that zooplankton migrated downwards from the epilimnion at night, and

357 zooplankton migration upwards from the hypolimnion at night was minor (S. Arnott,

358 unpublished). However, we may have underestimated metalimnetic production in invaded lakes,

359 as diel migrations from the warmer epilimnion at night to the cooler metalimnion during the day

360 may be a response of some zooplankton taxa to Bythotrephes. Dumitru and others (2001)

361 examined the effect of Bythotrephes on whole water column zooplankton production in a single

362 lake, and therefore did not consider the spatial distribution of production. Pangle and Peacor

363 (2006) and Pangle and others (2007) demonstrated that Bythotrephes can induce cladoceran taxa to

364 migrate into the hypolimnion to avoid predation, with significant costs as a result of exposure to

365 cooler temperatures: our results extend their findings to the entire zooplankton community over a

366 greater part of the ice-free season. The non-lethal costs of these migrations may be substantial.

367 Using Harp Lake as an example, we estimate that epilimnetic production would be about $44 \%$

368 greater if $\sim 50 \%$ of zooplankton (based on differences in hypolimnetic abundance between Harp 
and reference lakes) in the hypolimnion of Harp Lake are epilimnetic species that have behaviourally shifted habitats to avoid Bythotrephes.

There was considerable among-lake variability in response to the invasion of Bythotrephes.

372 Although the hypolimnion of some invaded lakes made substantial $(>25 \%)$ contributions to total

373 seasonal productivity, the hypolimnion contributed very little to overall productivity in other

374 invaded lakes $(<4 \%)$. This variability in invaded lakes may be partly due to differing planktivore

375 communities. Planktivores may influence the vertical distribution of Bythotrephes, which may, in

376 turn, influence the distribution of zooplankton. A concurrent study in two of our invaded lakes

377 revealed that Bythotrephes distribution is indeed related to the presence of the cold-water

378 planktivore, cisco (Young and Yan 2008), suggesting that other components of the food web may

379 mediate the effects of Bythotrephes on crustacean zooplankton.

380 In addition to spatial shifts in productivity, we observed seasonal shifts in invaded lakes

381 during periods when Bythotrephes was not present, i.e., in the spring before population growth

382 rates increase. In three of the four invaded lakes, there was a large pulse in small cladoceran

383 epilimnetic production early in the season, likely from above average egg production per

384 individual small cladoceran in two of the invaded lakes, in combination with greater abundances in

385 May and early June. This suggests that small cladocerans may alter their life history, at least in

386 some lakes, by shifting reproduction to earlier in the season to avoid the invader. This is in

387 agreement with another field study, where temporal shifts in copepod egg production were

388 observed as a result of the presence of a fish predator (Hairston Jr. and Walton 1986).

Increased production of other intermediate trophic levels may offset reduced epilimnetic

390 crustacean production. For instance, rotifers were more abundant in lakes invaded by

391 Bythotrephes, especially the colonial Conochilus (Hovius and others 2006), which has high

392 intrinsic rates of increase (Allan 1976) and is probably an inedible prey item for Bythotrephes. 
393 However, rotifers likely do not substitute for crustacean zooplankton as prey for fish (Threlkeld

394 1988). In addition, Sherwood and others (2002) showed that the lack of large-bodied prey groups

395 could reduce the efficiency of energy transfer to fish in metal-polluted lakes with simplified food

396 webs, implying that the loss of typical prey in invaded lakes may prevent higher trophic levels

397 from reaching their normal body size.

398 The spatial, temporal, and taxonomic redistribution of secondary production in

399 Bythotrephes-invaded lakes will likely have important implications for aquatic food webs. Shifts

400 in zooplankton reproduction from the epilimnion to the hypolimnion may negatively affect

401 epilimnetic-feeding fish species that rely on zooplankton, such as larval cisco, which inhabit

402 surface waters (Oyadomari and Auer 2004), and are highly reliant on crustaceans as their prey

403 (Davis and Todd 1998). In addition, cold-water planktivores (i.e., adult cisco), would be unlikely

404 to benefit from this shift since they have reduced foraging success in poorly-lit waters (Milne and 405 others 2005) and tend to prefer temperatures around $12^{\circ} \mathrm{C}$ (Rudstam and Magnuson 1985), which 406 falls into the metalimnion in most of our lakes.

407

Impact of Zooplankton on Phytoplankton

409 community by the zooplankton community, we did not observe the expected changes in

411 phytoplankton biomass (as measured by chlorophyll a) at the lake-level in Bythotrephes-invaded 412 lakes. Even though low productivity lakes, such as those in our study, are predicted to be 413 influenced more by bottom-up, rather than top-down, forces (Jeppeson and others 2003), 414 significant effects of zooplankton on phytoplankton biomass have been observed in other 415 oligotrophic lakes (Sarnelle and Knapp 2005). The weak overall effects of zooplankton on 416 phytoplankton echo the experimental results of Sommer and others (2001), where increased 
abundance of zooplankton functional groups had no effect on total phytoplankton biomass. Pérez-

418 Fuentetaja and others (2000) also found that zooplankton had a weak influence on chlorophyll in

419 oligo- and meso-trophic lakes. Thus, it appears that the invasion of Bythotrephes will probably not

420 have a large cascading effect on phytoplankton biomass in lower productivity lakes, despite large

421 reductions in epilimnetic zooplankton biomass $(>70 \%)$. However, more productive lakes may be

422 more likely to respond to top-down changes (Jeppesen and others 2003), and although

423 Bythotrephes seems to prefer oligotrophic lakes, it has been found in some mesotrophic systems

424 (Jarnagin and others 2000), suggesting that the invader may have the potential to instigate

425 increases in algal biomass in lakes of moderate productivity.

\section{ACKNOWLEDGEMENTS}

This project benefited from discussions with Ora Johannsson, Michael Arts, Beatrix Beisner,

Norman Yan, Jon Hovius, Joelle Young, Sophie Foster, Gary Sprules, William Taylor, Lisa

Nordin, and Robert Girard. We thank B. Beisner, O. Johannsson, J. Young, Michael Vanni, and

two anonymous reviewers for comments on the manuscript. We are grateful to the Ontario

432 Ministry of Natural Resources for providing fish data. We would also like to thank J. Hovius,

433 Emily Parrott, and Greg Puncher for assistance in the field, and E. Parrott for enumerating the

434 Bythotrephes samples. Funding for this project was provided by a Natural Sciences and

435 Engineering Research Council of Canada Discovery Grant to SEA and Post-Graduate Scholarship

436 to ALS, the Department of Fisheries and Oceans Canada, the Ontario Ministry of the

437 Environment, and Queen's University School of Graduate Studies and Research. Logistical

438 support and water chemistry was provided by the Dorset Environmental Science Centre. 
441 Allan, JD. 1976. Life history patterns in zooplankton. The American Naturalist 110: 165-80.

442 Allen, G, Yan ND, Geiling WT. 1994. ZEBRA2- Zooplankton enumeration and biomass routines

443 for APIOS: a semi-automated sample processing system for zooplankton ecologists.

444 Dorset, ON: Ontario Ministry of Environment and Energy.

445 Beauchamp, DA, Sergeant CJ, Mazur MM, Scheuerell JM, Schindler DE, Scheuerell MD, Fresh

446 KL, Seiler DE, Quinn TP. 2004. Spatial-temporal dynamics of early feeding demand and food supply for sockeye salmon fry in Lake Washington. Transactions of the American Fisheries Society 133: 1014-32.

Borgmann, U, Shear H, Moore J. 1984. Zooplankton and potential fish production in Lake Ontario. Canadian Journal of Fisheries and Aquatic Sciences 41: 1303-9.

451 Boudreau, SA, Yan ND. 2003. The differing crustacean zooplankton communities of Canadian Shield lakes with and without the nonindigenous zooplanktivore Bythotrephes longimanus. Canadian Journal of Fisheries and Aquatic Sciences 60: 1307-13.

Branstrator, DK, Brown ME, Shannon LJ, Thabes M, Heimgartner K. 2006. Range expansion of Bythotrephes longimanus in North America: evaluating habitat characteristics in the spread

Brooks, ML, D'Antonio CM, Richardson DM, Grace JB, Keeley JE, DiTomaso JM, Hobbs RJ, of an exotic zooplankter. Biological Invasions 8: 1367-79.

Chick, JH, van den Avyle MJ. 1999. Zooplankton variability and larval striped bass foraging: evaluating potential match/mismatch regulation. Ecological Applications 9: 320-34. zooplankton from length-weight regressions. Canadian Journal of Fisheries and Aquatic Sciences 42: 1380-90. 
464 Cyr, H. 1998. Cladoceran- and copepod-dominated zooplankton communities graze at similar rates in low productivity lakes. Canadian Journal of Fisheries and Aquatic Sciences 55: 414-22.

Davis, BM, Todd TN. 1998. Competition between larval lake herring (Coregonus artedi) and lake whitefish (Coregonus clupeaformis) for zooplankton. Canadian Journal of Fisheries and Aquatic Sciences 55: 1140-8.

Downing, JA. 1984. Assessment of secondary production: the first step. In: Downing JA, Rigler $\mathrm{FH}$, Eds. A manual on the methods for the assessment of secondary productivity in freshwaters. Oxford, UK: Blackwell Scientific Publications. p 1-18.

Dumitru, C, Sprules WG, Yan ND. 2001. Impact of Bythotrephes longimanus on zooplankton assemblages of Harp Lake, Canada: an assessment based on predator consumption and prey production. Freshwater Biology 46: 241-51.

Elser, JJ, Goldman CR. 1991. Zooplankton effects on phytoplankton in lakes of contrasting trophic status. Limnology and Oceanography 36: 64-90.

Elser, JJ, Sterner RW, Galford AE, Chrzanowski TH, Findlay DL, Mills KH, Paterson MJ, Stainton MP, Schindler DW. 2000. Pelagic C:N:P stoichiometry in a eutrophied lake: responses to a whole-lake food-web manipulation. Ecosystems 3: 293-307.

Hairston Jr., NG, Walton WE. 1986. Rapid evolution of a life history trait. Proceedings of the National Academy of Sciences of the United States of America 83: 4831-3.

Hovius, JT, Beisner BE, McCann KS. 2006. Epilimnetic rotifer community responses to 483 Bythotrephes longimanus invasion in Canadian Shield lakes. Limnology and Oceanography 51: 1004-12.

Jarnagin, ST, Swan BK, Kerfoot WC. 2000. Fish as vectors in the dispersal of Bythotrephes cederstroemi: diapausing eggs survive passage through the gut. Freshwater Biology 43: 579-89. 
Jeppesen, E, Jensen JP, Jensen C, Faafeng BA, Hessen DO, Søndergaard M, Lauridsen T, Brettum P, Christoffersen K. 2003. The impact of nutrient state and lake depth on top-down control in the pelagic zone of lakes: a study of 466 lakes from the temperate zone to the Arctic. Ecosystems 6: 313-25.

Jin, EH, Sprules WG. 1990. Distribution and abundance of Bythotrephes cederstroemi (Cladocera: Cercopagidae) in the St. Lawrence Great Lakes. Verhandlungen Internationale Vereinigung für theoretische und angewandte Limnologie 24: 383-5.

Kuns, MM, Sprules WG. 2000. Zooplankton production in Lake Ontario: a multistrata approach. Canadian Journal of Fisheries and Aquatic Sciences 57: 2240-7.

Lampert, W. 1989. The adaptive significance of diel vertical migration of zooplankton. Functional Ecology 3: 21-7.

Loreau, M, Naeem S, Inchausti P, Bengtsson J, Grime JP, Hector A, Hooper DU, Huston MA, Raffaelli D, Schmid B, Tilman D, Wardle DA. 2001. Biodiversity and ecosystem functioning: current knowledge and future challenges. Science 294: 804-8.

MacIsaac, HJ, Ketelaars HAM, Grigorovich IA, Ramcharan CW, Yan ND. 2000. Modeling Bythotrephes longimanus invasions in the Great Lakes basin based on its European distribution. Archiv für Hydrobiologie 149: 1-21.

McCauley, E. 1984. The estimation of the abundance and biomass of zooplankton in samples. In: Downing JA, Rigler FH, Eds. A manual on the methods for the assessment of secondary productivity in freshwaters. Oxford, UK: Blackwell Scientific Publications. p 228-65. Millenium Ecosystem Assessment. 2005. Ecosystems and human well-being: biodiversity synthesis. ed. Washington, DC: World Resources Institute. 
Milne, SW, Shuter BJ, Sprules WG. 2005. The schooling and foraging ecology of lake herring (Coregonus artedi) in Lake Opeongo, Ontario, Canada. Canadian Journal of Fisheries and Aquatic Sciences 62: 1210-8.

Oyadomari, JK, Auer NA. 2004. Inshore-offshore distribution of larval fishes in Lake Superior off the western coast of the Keweenaw Peninsula, Michigan. Journal of Great Lakes Research 30 (Suppl. 1): 369-84.

Paloheimo, JE. 1974. Calculations of instantaneous birth rate. Limnology and Oceanography 19: $692-4$.

Pangle, KL, Peacor SD. 2006. Non-lethal effect of the invasive predator Bythotrephes longimanus on Daphnia mendotae. Freshwater Biology 51: 1070-8.

Pangle, KL, Peacor SD, Johannsson OE. 2007. Large nonlethal effects of an invasive invertebrate predator on zooplankton population growth rate. Ecology 88: 402-12.

Pérez-Fuentetaja, A, McQueen DJ, Yan ND, Dillon PJ. 2000. Zooplankton biomass rarely improves predictions of chlorophyll concentration in Canadian Shield lakes that vary in pH. Aquatic Ecology 34: 127-36.

Ramcharan, CW, Pérez-Fuentetaja A, McQueen DJ, Yan ND, Demers E, Rusak JA. 2001. Dynamics of zooplankton productivity under two different predatory regimes. Archiv für Hydrobiologie Special Issues: Advances in Limnology 56: 151-69.

Rudstam, LG, Magnuson JJ. 1985. Predicting the vertical distribution of fish populations: analysis of cisco, Coregonus artedii, and yellow perch, Perca flavescens. Canadian Journal of Fisheries and Aquatic Sciences 42: 1178-88.

Sala, OE, Chapin III FS, Armesto JJ, Berlow E, Bloomfield J, Dirzo R, Huber-Sanwald E, Huenneke LF, Jackson RB, Kinzig A, Leemans R, Lodge DM, Mooney HA, Oesterheld M, 

for the year 2100. Science 287: 1770-4.

Sarnelle, O, Knapp RA. 2005. Nutrient recycling by fish versus zooplankton grazing as drivers of the trophic cascade in alpine lakes. Limnology and Oceanography 50: 2032-42.

Sherwood, GD, Kovecses J, Hontela A, Rasmussen JB. 2002. Simplified food webs lead to energetic bottlenecks in polluted lakes. Canadian Journal of Fisheries and Aquatic Sciences 59: $1-5$.

Simon, KS, Townsend CR. 2003. Impacts of freshwater invaders at different levels of ecological organisation, with emphasis on salmonids and ecosystem consequences. Freshwater Biology 48: 982-94.

Sommer, U, Sommer F, Santer B, Jamieson B, Boersma M, Becker C, Hansen T. 2001. Complementary impact of copepods and cladocerans on phytoplankton. Ecology Letters 4: $545-50$.

Sprules, WG. 1980. Zoogeographic patterns in the size structure of zooplankton communities, with possible applications to lake ecosystem modeling and management. In: Kerfoot WC, Ed. Evolution and ecology of zooplankton communities. Hanover, NH: University Press of New England. p 642-56.

StatSoft. 2001. STATISTICA 6. Tulsa, Oklahoma, USA: StatSoft Inc.

Strecker, AL, Arnott SE. 2005. Impact of Bythotrephes invasion on zooplankton communities in acid-damaged and recovered lakes on the Boreal Shield. Canadian Journal of Fisheries and Aquatic Sciences 62: 2450-62.

Strecker, AL, Arnott SE, Yan ND, Girard R. 2006. Variation in the response of crustacean zooplankton species richness and composition to the invasive predator Bythotrephes longimanus. Canadian Journal of Fisheries and Aquatic Sciences 63: 2126-36. 
Threlkeld, ST. 1988. Planktivory and planktivore biomass effects on zooplankton, phytoplankton, and the trophic cascade. Limnology and Oceanography 33: 1362-75.

Wilcove, DS, Rothstein D, Dubow J, Phillips A, Losos E. 1998. Quantifying threats to imperiled species in the United States. BioScience 48: 607-15.

Yan, ND, Blukacz A, Sprules WG, Kindy PK, Hackett D, Girard RE, Clark BJ. 2001. Changes in zooplankton and the phenology of the spiny water flea, Bythotrephes, following its invasion of Harp Lake, Ontario, Canada. Canadian Journal of Fisheries and Aquatic Sciences 58: 2341-50.

Yan, ND, Girard RE, Boudreau S. 2002. An introduced invertebrate predator (Bythotrephes) reduces zooplankton species richness. Ecology Letters 5: 481-5.

Yan, ND, Mackie GL. 1987. Improved estimation of the dry weight of Holopedium gibberum (Crustacea, Cladocera) using clutch size, a body fat index, and lake water total phosphorus concentration. Canadian Journal of Fisheries and Aquatic Sciences 44: 382-9.

Yan, ND, Pawson TW. 1997. Changes in the crustacean zooplankton community of Harp Lake, Canada, following invasion by Bythotrephes cederstroemi. Freshwater Biology 37: 409-25.

Young, JD, Yan ND. 2008. Modification of the diel vertical migration of Bythotrephes longimanus by the cold-water planktivore, Coregonus artedi. Freshwater Biology in press.

Zhu, B, Fitzgerald DG, Mayer CM, Rudstam LG, Mills EL. 2006. Alteration of ecosystem function by zebra mussels in Oneida Lake: impacts on submerged macrophytes. Ecosystems 9: 1017-28. 
578 APPENDIX 1. Planktivorous fish and Mysis relicta categorical abundance in study lakes. Fish data 579 provided by Ontario Ministry of Natural Resources (unpublished) and Mysis data from Nordin 580 (2005). Lakes sorted by increasing Bythotrephes abundance.

\begin{tabular}{lccccc}
\hline \hline & & Rainbow & Lake & Yellow & \\
Lake & Cisco & smelt & whitefish & perch & Mysis \\
& (Coregonus & (Osmerus & (Coregonus & (Perca & relicta \\
& artedi) & mordax) & clupeaformis) & flavescens) & \\
\hline
\end{tabular}

Not Invaded

$\begin{array}{lccccc}\text { Buck } & \text { A/P } & \text { A } & \text { A } & \text { P } & \text { H } \\ \text { Doe } & \text { L } & \text { A } & \text { L } & \text { P } & \text { L } \\ \text { Pickerel } & \text { L } & \text { A } / \text { P } & \text { A } & \text { P } & \text { H } \\ \text { Sand } & \text { L } & \text { H } & \text { A } & \text { P } & \text { L }\end{array}$

Invaded

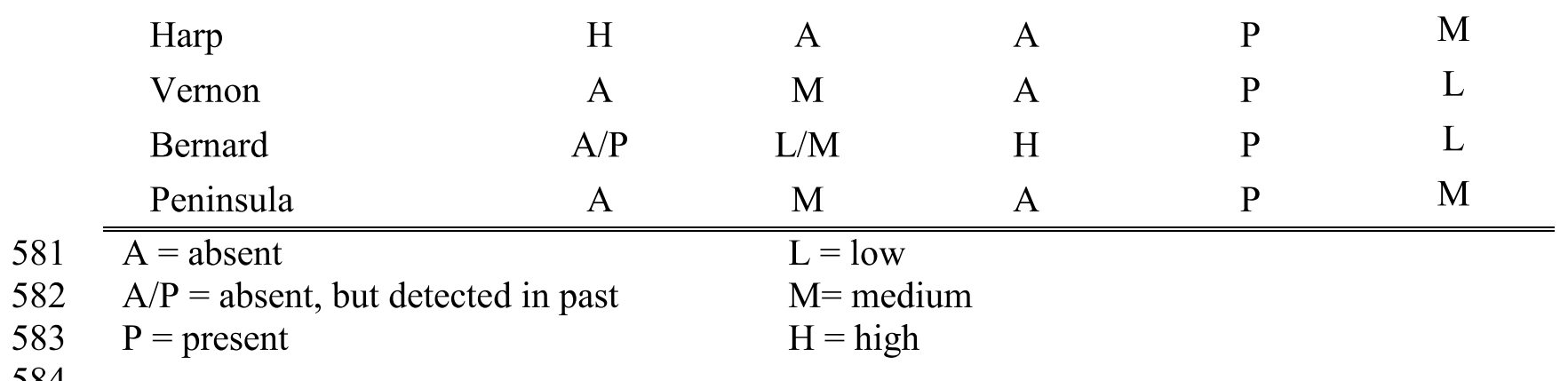

585

586

587

588

589

590

591

592 


\section{FIGURE CAPTIONS}

594

595

596

597

598

599

600

601

602

603

604

605

606

607

608

609

610

611

612

613

614

615

616

Figure 1. Total secondary production $\left(\mathrm{mg} \mathrm{m}^{-2}\right.$ season $\left.^{-1}\right)$ of Bythotrephes $(\boldsymbol{\square})$ and zooplankton in the epilimnion $(\square)$, metalimnion $(\square)$, and hypolimnion $(\square)$ of invaded and reference lakes. For the purposes of our study, we define the season as the middle of May to the middle of September.

Figure 2. On the left axis, average secondary production of zooplankton of invaded $(\square)$ and reference $(\square)$ lakes $\left(\mathrm{mg} \mathrm{m}^{-2}\right.$ fortnight $\left.{ }^{-1}\right)$ and on the right axis, average seasonal production $\left(\mathrm{mg} \mathrm{m}^{-2}\right.$ season $^{-1}$ ) of invaded ( $\square$ ) and reference ( $\square$ ) lakes in the (a) epilimnion, (b) metalimnion, and (c) hypolimnion $(n=4$, except reference lake hypolimnion where $n=3)$. Production is calculated from two adjacent sampling dates, so the value shown represents that of the following two-week interval, i.e. the value from the middle of May represents the sampling period from then until early June. Sampling occurred approximately fortnightly (mean: 13.5 days) and we define the season as the middle of May to the middle of September. Error bars are \pm 1 standard error.

Figure 3. Average biweekly secondary production $\left(\mathrm{mg} \mathrm{m}^{-2}\right.$ fortnight $\left.^{-1}\right)$ in calanoids (a-c), cyclopoids (d-f), large cladocerans (g-i), and small cladocerans (j-1) in the epi-, meta-, and hypolimnion of invaded $(\square)$ and reference $(\boldsymbol{\square})$ lakes $(\mathrm{n}=4$, except reference lake hypolimnion where $n=3$ ). Sampling occurred approximately fortnightly (mean: 13.5 days). Error bars are \pm 1 standard error.

Figure 4. Average abundance of small cladocerans, large cladocerans, cyclopoids, and calanoids (individuals $\mathrm{L}^{-1}$ ) in the epilimnion (a-b), metalimnion (c-d), and hypolimnion (e-f) of invaded and reference lakes. 
617 Figure 5. Average number of eggs individual ${ }^{-1}$ of entire zooplankton community in each strata in

618 invaded ( $\square$ ) and reference ( $\square$ ) lakes (left column: a,d,g) and for each functional group in the

619 epilimnion $(\mathrm{b}, \mathrm{c})$, metalimnion $(\mathrm{e}, \mathrm{f})$, and hypolimnion $(\mathrm{h}, \mathrm{i})$ of invaded and reference lakes $(\mathrm{n}=4$,

620 except reference lake hypolimnion where $n=3$ ). Error bars are \pm 1 standard error. Note that the

621 ratio of eggs to individuals for separate functional groups does not sum to equal the average of the

622 entire community as a result of different densities of zooplankton in each group.

624 Figure 6. Epi- and metalimnetic zooplankton production $\left(\diamond ; \mathrm{mg} \mathrm{m}^{-2}\right.$ fortnight $\left.{ }^{-1}\right)$ and Bythotrephes

625 consumption $\left(\mathbf{\square} ; \mathrm{mg} \mathrm{m}^{-2}\right.$ fortnight $\left.^{-1}\right)$ in invaded lakes, contrasted with Bythotrephes abundance

$626\left(\triangle\right.$; individuals $\left.\mathrm{m}^{-3}\right)$ on the right axis. In each panel, the top bracketed value is the percent of total 627 seasonal zooplankton production consumed by Bythotrephes, and the bottom bracketed value is 628 the percent of seasonal production consumed by Bythotrephes starting in the middle of June.

629 Asterisk (*) indicates the dates on which Bythotrephes consumption exceeded zooplankton 630 production. Sampling occurred approximately fortnightly (mean: 13.5 days).

631

632 Figure 7. (a) Percent change in algae during zooplankton impact experiment in invaded $(\square ; \mathrm{n}=2)$

633 and reference lakes $(\square ; n=3)$. Positive values indicate that phytoplankton increased during the 634 experiment, while negative numbers indicate a decrease in algae. (b) Total chlorophyll $a\left(\mu \mathrm{g} \mathrm{L}^{-1}\right)$ 635 of all invaded $(\square)$ and reference $(\square)$ lakes $(n=4)$. Error bars are \pm 1 standard error. 


\section{TABLE CAPTIONS}

638 Table 1. Morphometric, physical, chemical, and biotic characteristics of study lakes. A one-way

639 ANOVA was performed on parameters $(n=4$, treatment $\mathrm{df}=1$, error $\mathrm{df}=6)$. Lakes sorted by

640 increasing Bythotrephes abundance. Lat $=$ latitude, long $=$ longitude, $Z_{\max }=$ maximum depth, $\mathrm{Ca}=$

641 calcium, $\mathrm{DOC}=$ dissolved organic carbon, Cond $=$ conductivity, $\mathrm{TP}=$ total phosphorus, $\operatorname{chl} a=$

642 chlorophyll $a$.

643

644 Table 2. Repeated measures ANOVAs on stratified and whole water column zooplankton

645 secondary production, total zooplankton abundance, and eggs individual ${ }^{-1}$. The mean effect size of

646 production is calculated by summing all the sampling dates and then averaging between lakes in

647 each category. The mean effect size of abundance and eggs individual ${ }^{-1}$ is calculated by averaging

648 all of the lakes in each category on all dates.

649

650 Table 3. Repeated measures ANOVAs on zooplankton secondary production for each functional

651 group. The mean effect size of production is calculated by summing all the sampling dates and

652 then averaging between lakes in each category.

653

654 Table 4. Repeated measures ANOVAs on zooplankton egg production per individual for each

655 functional group. The mean effect size is calculated by averaging all of the lakes in each category

656 on all dates 


\begin{tabular}{|c|c|c|c|c|c|c|c|c|c|}
\hline Lake & $\begin{array}{l}\text { Lat } \\
\text { Long }\end{array}$ & $\begin{array}{l}Z_{\max } \\
(\mathrm{m})\end{array}$ & $\begin{array}{c}\text { Area } \\
\text { (ha) }\end{array}$ & $\begin{array}{c}\mathrm{Ca} \\
\left(\mathrm{mg} \mathrm{L}^{-1}\right)\end{array}$ & $\begin{array}{c}\mathrm{DOC} \\
\left(\mathrm{mg} \mathrm{L}^{-1}\right)\end{array}$ & $\begin{array}{l}\text { Cond } \\
(\mu \mathrm{mhos} \\
\left.\mathrm{cm}^{-1}\right)\end{array}$ & $\mathrm{pH}$ & $\begin{array}{c}\mathrm{TP} \\
\left(\mu \mathrm{g} \mathrm{L}^{-1}\right)\end{array}$ & $\begin{array}{c}\text { Mean } \\
\text { total } \\
\text { chl } a \\
\left(\mu \mathrm{g} \mathrm{L}^{-1}\right)\end{array}$ \\
\hline \multicolumn{10}{|l|}{ Reference } \\
\hline Buck* & $\begin{array}{l}45^{\circ} 25^{\prime} \mathrm{N}, \\
79^{\circ} 23^{\prime} \mathrm{W}\end{array}$ & 23.0 & 656.0 & 2.6 & 10.7 & 25.6 & 6.3 & 13.3 & 2.8 \\
\hline Doe* & $\begin{array}{l}45^{\circ} 32^{\prime} \mathrm{N}, \\
79^{\circ} 25^{\prime} \mathrm{W}\end{array}$ & 23.0 & 1187.0 & 3.6 & 7.0 & 46.0 & 7.1 & 12.0 & 3.4 \\
\hline Pickerel* & $\begin{array}{l}45^{\circ} 41^{\prime} \mathrm{N} \\
79^{\circ} 18^{\prime} \mathrm{W}\end{array}$ & 38.0 & 513.0 & 2.8 & 6.7 & 32.4 & 6.8 & 8.1 & 4.4 \\
\hline Sand & $\begin{array}{l}45^{\circ} 37^{\prime} \mathrm{N} \\
79^{\circ} 10^{\prime} \mathrm{W}\end{array}$ & 59.0 & 568.2 & 3.5 & 6.0 & 37.2 & 6.8 & 7.1 & 2.0 \\
\hline Mean & & 35.8 & 731.1 & 3.1 & 7.6 & 35.3 & 6.8 & 10.1 & 3.1 \\
\hline \multicolumn{10}{|l|}{ Invaded } \\
\hline Harp* & $\begin{array}{l}45^{\circ} 23^{\prime} \mathrm{N}, \\
79^{\circ} 07^{\prime} \mathrm{W}\end{array}$ & 37.5 & 71.7 & 3.0 & 6.7 & 38.0 & 7.0 & 7.2 & 1.7 \\
\hline Vernon* & $\begin{array}{l}45^{\circ} 20^{\prime} \mathrm{N} \\
79^{\circ} 17^{\prime} \mathrm{W}\end{array}$ & 37.2 & 1505.1 & 3.0 & 7.1 & 36.8 & 6.8 & 7.9 & 2.8 \\
\hline Bernard & $\begin{array}{l}45^{\circ} 45^{\prime} \mathrm{N}, \\
79^{\circ} 23^{\prime} \mathrm{W}\end{array}$ & 47.9 & 2057.7 & 4.1 & 3.4 & 65.2 & 7.1 & 9.6 & 2.8 \\
\hline Peninsula & $\begin{array}{l}45^{\circ} 20^{\prime} \mathrm{N} \\
79^{\circ} 06^{\prime} \mathrm{W}\end{array}$ & 34.1 & 864.8 & 4.4 & 6.1 & 70.6 & 7.1 & 9.0 & 2.6 \\
\hline Mean & & 39.2 & 1124.8 & 3.6 & 5.8 & 52.7 & 7.0 & 8.4 & 2.5 \\
\hline$F$-ratio & & 0.14 & 0.75 & 1.04 & 1.74 & 3.10 & 1.96 & 1.16 & 1.51 \\
\hline$p$-value & & 0.72 & 0.42 & 0.35 & 0.23 & 0.13 & 0.21 & 0.32 & 0.27 \\
\hline
\end{tabular}

$658 *$ lakes included in grazing experiment

659 
TABLE 2.

\begin{tabular}{|c|c|c|c|c|c|c|c|c|}
\hline \multirow{2}{*}{ Measure } & \multirow{2}{*}{ Stratum } & \multicolumn{2}{|c|}{ Invasion } & \multicolumn{2}{|c|}{ Time } & \multicolumn{2}{|c|}{ Time $\times$ Invasion } & \multirow{2}{*}{$\begin{array}{c}\text { Mean } \\
\text { effect } \\
\text { size }\end{array}$} \\
\hline & & $F_{1,6}$ & $p$ & $F_{7,42}{ }^{\mathrm{a}}$ & $p$ & $F_{7,42}{ }^{\mathrm{a}}$ & $p$ & \\
\hline \multirow{4}{*}{$\begin{array}{l}\text { Secondary } \\
\text { production }\end{array}$} & Epilimnion & 9.68 & $0.02 *$ & 2.13 & 0.11 & 1.31 & 0.29 & $-67 \%$ \\
\hline & Metalimnion & 0.03 & 0.87 & 5.19 & $<0.01^{*}$ & 0.58 & 0.75 & $+15 \%$ \\
\hline & Hypolimnion & 3.46 & 0.12 & 1.77 & 0.13 & 0.43 & 0.88 & $+766 \%$ \\
\hline & All strata & 1.24 & 0.31 & 1.85 & 0.14 & 0.64 & 0.65 & $-35 \%$ \\
\hline \multirow{4}{*}{$\begin{array}{l}\text { Total } \\
\text { abundance }\end{array}$} & Epilimnion & 16.91 & $<0.01^{*}$ & 17.48 & $<0.01 *$ & 6.55 & $<0.01^{*}$ & $-59 \%$ \\
\hline & Metalimnion & 0.80 & 0.40 & 8.08 & $<0.01^{*}$ & 0.80 & 0.56 & $+55 \%$ \\
\hline & Hypolimnion & 1.78 & 0.24 & 4.02 & $<0.01 *$ & 0.50 & 0.85 & $+137 \%$ \\
\hline & All strata & 0.42 & 0.54 & 12.03 & $<0.01^{*}$ & 0.80 & 0.61 & $-17 \%$ \\
\hline \multirow{4}{*}{$\begin{array}{l}\text { Eggs } \\
\text { individual }^{-1}\end{array}$} & Epilimnion & 1.90 & 0.22 & 1.56 & 0.19 & 1.06 & 0.41 & $-17 \%$ \\
\hline & Metalimnion & 0.01 & 0.91 & 2.86 & $0.08 \dagger$ & 0.19 & 0.88 & $+10 \%$ \\
\hline & Hypolimnion $\ddagger$ & 6.04 & $0.06 \dagger$ & 4.70 & $0.02 *$ & 1.63 & 0.23 & $+213 \%$ \\
\hline & All strata & 1.74 & 0.24 & 3.58 & $<0.01^{*}$ & 1.52 & 0.20 & $-20 \%$ \\
\hline
\end{tabular}

$661 * 0<0.05, \dagger p<0.10$

$662+$ Invasion error $\mathrm{df}=5$, Time $\times$ Invasion error $\mathrm{df}=35$; total abundance Time $\times$ Invasion

663 error $\mathrm{df}=40$

664 a total abundance: $F_{8,48}$ 
TABLE 3.

\begin{tabular}{|c|c|c|c|c|c|c|c|c|}
\hline \multirow[t]{2}{*}{ Stratum } & \multirow{2}{*}{$\begin{array}{l}\text { Functional } \\
\text { group }\end{array}$} & \multicolumn{2}{|c|}{ Invasion } & \multicolumn{2}{|c|}{ Time } & \multicolumn{2}{|c|}{$\begin{array}{c}\text { Time } \times \\
\text { Invasion }\end{array}$} & \multirow{2}{*}{$\begin{array}{c}\text { Mean } \\
\text { effect } \\
\text { size }\end{array}$} \\
\hline & & $F_{1,6}$ & $p$ & $F_{7,42}$ & $p$ & $F_{7,42}$ & $p$ & \\
\hline \multirow{4}{*}{ Epilimnion } & calanoids & 10.50 & $0.02 *$ & 3.95 & $<0.01^{*}$ & 0.77 & 0.62 & $-90 \%$ \\
\hline & cyclopoids & 54.02 & $<0.01 *$ & 4.10 & $<0.01^{*}$ & 1.64 & 0.17 & $-57 \%$ \\
\hline & $\begin{array}{c}\text { large } \\
\text { cladocerans }\end{array}$ & 2.48 & 0.17 & 1.62 & 0.21 & 0.14 & 0.95 & $-61 \%$ \\
\hline & $\begin{array}{c}\text { small } \\
\text { cladocerans }\end{array}$ & 24.97 & $<0.01^{*}$ & 3.45 & $0.02 *$ & 5.45 & $<0.01^{*}$ & $-17 \%$ \\
\hline \multirow{4}{*}{ Metalimnion } & calanoids & 2.71 & 0.15 & 3.79 & $0.02 *$ & 0.53 & 0.71 & $+250 \%$ \\
\hline & cyclopoids & 0.05 & 0.83 & 4.61 & $0.01^{*}$ & 0.56 & 0.65 & $+45 \%$ \\
\hline & $\begin{array}{c}\text { large } \\
\text { cladocerans }\end{array}$ & 2.07 & 0.20 & 4.01 & $<0.01^{*}$ & 2.12 & $0.07 \dagger$ & $-90 \%$ \\
\hline & $\begin{array}{c}\text { small } \\
\text { cladocerans }\end{array}$ & 0.04 & 0.85 & 1.64 & 0.19 & 1.47 & 0.24 & $+96 \%$ \\
\hline \multirow{4}{*}{ Hypolimnion } & calanoids & 9.70 & $0.03 *$ & 1.15 & 0.36 & 0.43 & 0.81 & $+61 \%$ \\
\hline & cyclopoids & 0.35 & 0.58 & 5.48 & $<0.01^{*}$ & 1.97 & $0.09 \dagger$ & $+964 \%$ \\
\hline & $\begin{array}{c}\text { large } \\
\text { cladocerans }\end{array}$ & 0.57 & 0.48 & 2.08 & 0.17 & 0.52 & 0.61 & $+6188 \%$ \\
\hline & $\begin{array}{c}\text { small } \\
\text { cladocerans }\end{array}$ & 0.03 & 0.88 & 1.77 & 0.18 & 0.79 & 0.53 & $-4 \%$ \\
\hline
\end{tabular}

$667 \$$ Invasion error $\mathrm{df}=5$, Time $\times$ Invasion error $\mathrm{df}=35$ 
TABLE 4.

\begin{tabular}{|c|c|c|c|c|c|c|c|c|}
\hline \multirow[t]{2}{*}{ Stratum } & \multirow{2}{*}{$\begin{array}{l}\text { Functional } \\
\text { group }\end{array}$} & \multicolumn{2}{|c|}{ Invasion } & \multicolumn{2}{|c|}{ Time } & \multicolumn{2}{|c|}{$\begin{array}{l}\text { Time } \times \\
\text { Invasion }\end{array}$} & \multirow{2}{*}{$\begin{array}{c}\text { Mean } \\
\text { effect } \\
\text { size }\end{array}$} \\
\hline & & $F_{1,6}$ & $p$ & $F_{7,42}$ & $p$ & $F_{7,42}$ & $p$ & \\
\hline \multirow{4}{*}{ Epilimnion } & calanoids & 3.15 & 0.13 & 1.16 & 0.35 & 1.01 & 0.40 & $-72 \%$ \\
\hline & cyclopoids & 0.01 & 0.92 & 0.95 & 0.40 & 1.37 & 0.29 & $7 \%$ \\
\hline & $\begin{array}{l}\text { large } \\
\text { cladocerans }\end{array}$ & 0.65 & 0.45 & 2.42 & $0.09 \dagger$ & 0.67 & 0.59 & $75 \%$ \\
\hline & $\begin{array}{l}\text { small } \\
\text { cladocerans }\end{array}$ & 0.02 & 0.89 & 2.58 & $0.05 *$ & 0.41 & 0.82 & $-4 \%$ \\
\hline \multirow{4}{*}{ Metalimnion } & calanoids & 3.02 & 0.13 & 0.61 & 0.54 & 0.71 & 0.49 & $295 \%$ \\
\hline & cyclopoids & 0.09 & 0.77 & 2.59 & 0.12 & 0.08 & 0.92 & $-17 \%$ \\
\hline & $\begin{array}{l}\text { large } \\
\text { cladocerans }\end{array}$ & 1.90 & 0.22 & 1.26 & 0.32 & 0.40 & 0.77 & $-54 \%$ \\
\hline & $\begin{array}{l}\text { small } \\
\text { cladocerans }\end{array}$ & 0.07 & 0.80 & 3.01 & $0.05 *$ & 1.55 & 0.23 & $11 \%$ \\
\hline \multirow{4}{*}{ Hypolimnion $\$$} & calanoids & 2.54 & 0.17 & 0.95 & 0.44 & 0.51 & 0.69 & $253 \%$ \\
\hline & cyclopoids & 4.04 & $0.10 \dagger$ & 4.92 & $0.03 *$ & 3.44 & $0.07 \dagger$ & $157 \%$ \\
\hline & $\begin{array}{l}\text { large } \\
\text { cladocerans }\end{array}$ & 0.01 & 0.99 & 1.20 & 0.34 & 1.26 & 0.33 & $-2 \%$ \\
\hline & $\begin{array}{l}\text { small } \\
\text { cladocerans }\end{array}$ & 1.20 & 0.32 & 3.12 & $0.08 \dagger$ & 1.06 & 0.39 & $67 \%$ \\
\hline
\end{tabular}

$671+$ Invasion error $\mathrm{df}=5$, Time $\times$ Invasion error $\mathrm{df}=35$

672

673 


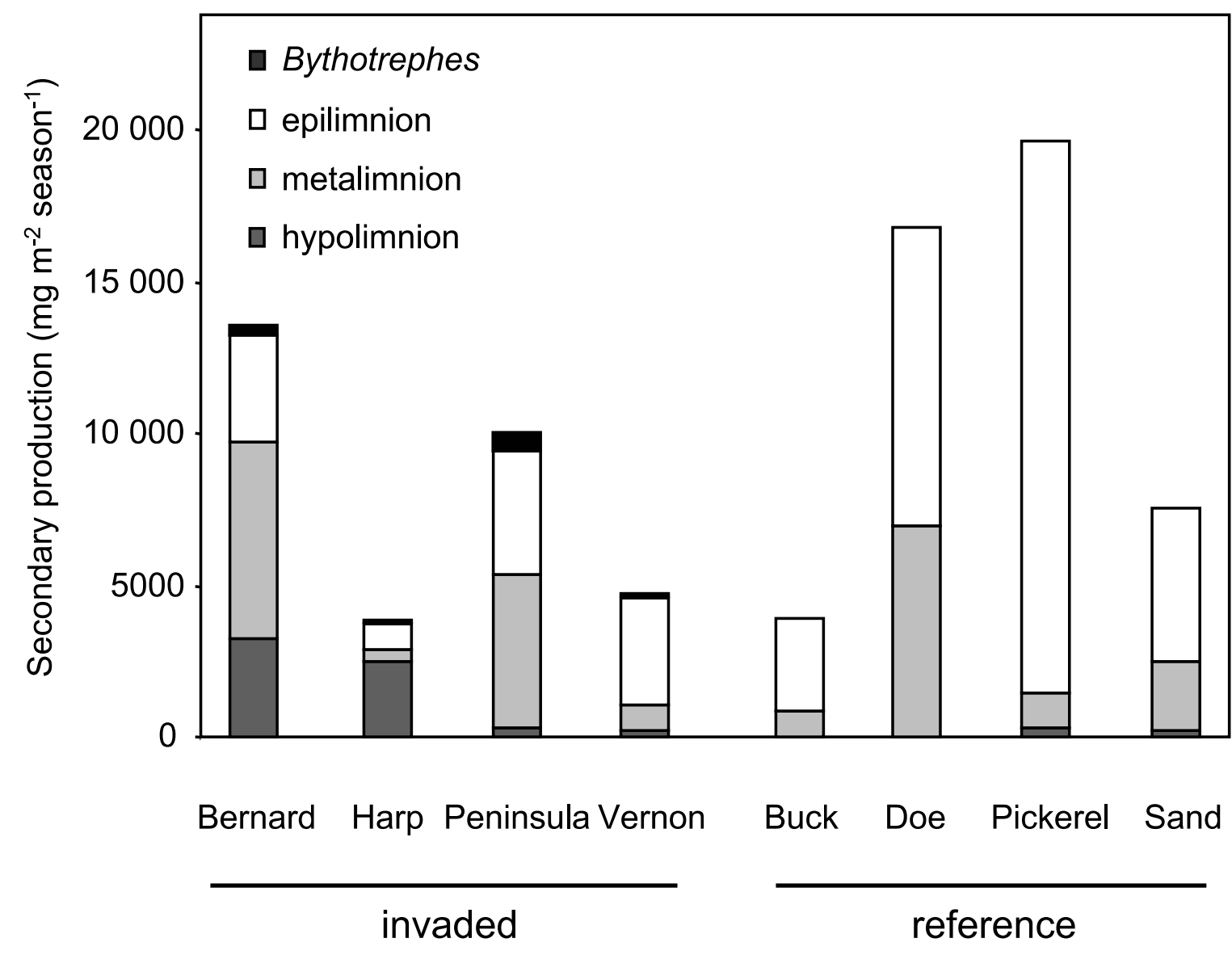

Fig. 1 


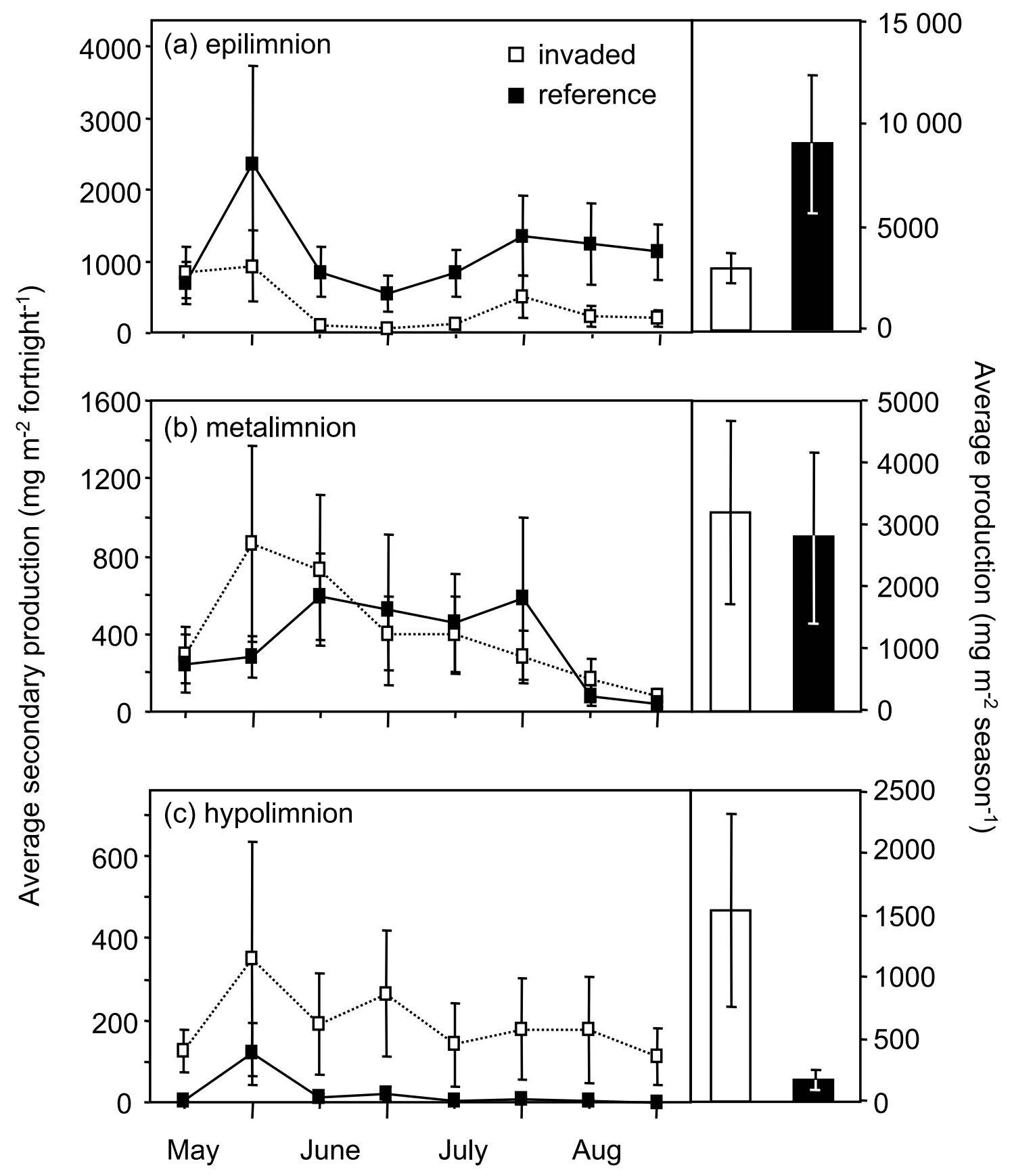

Fig. 2 


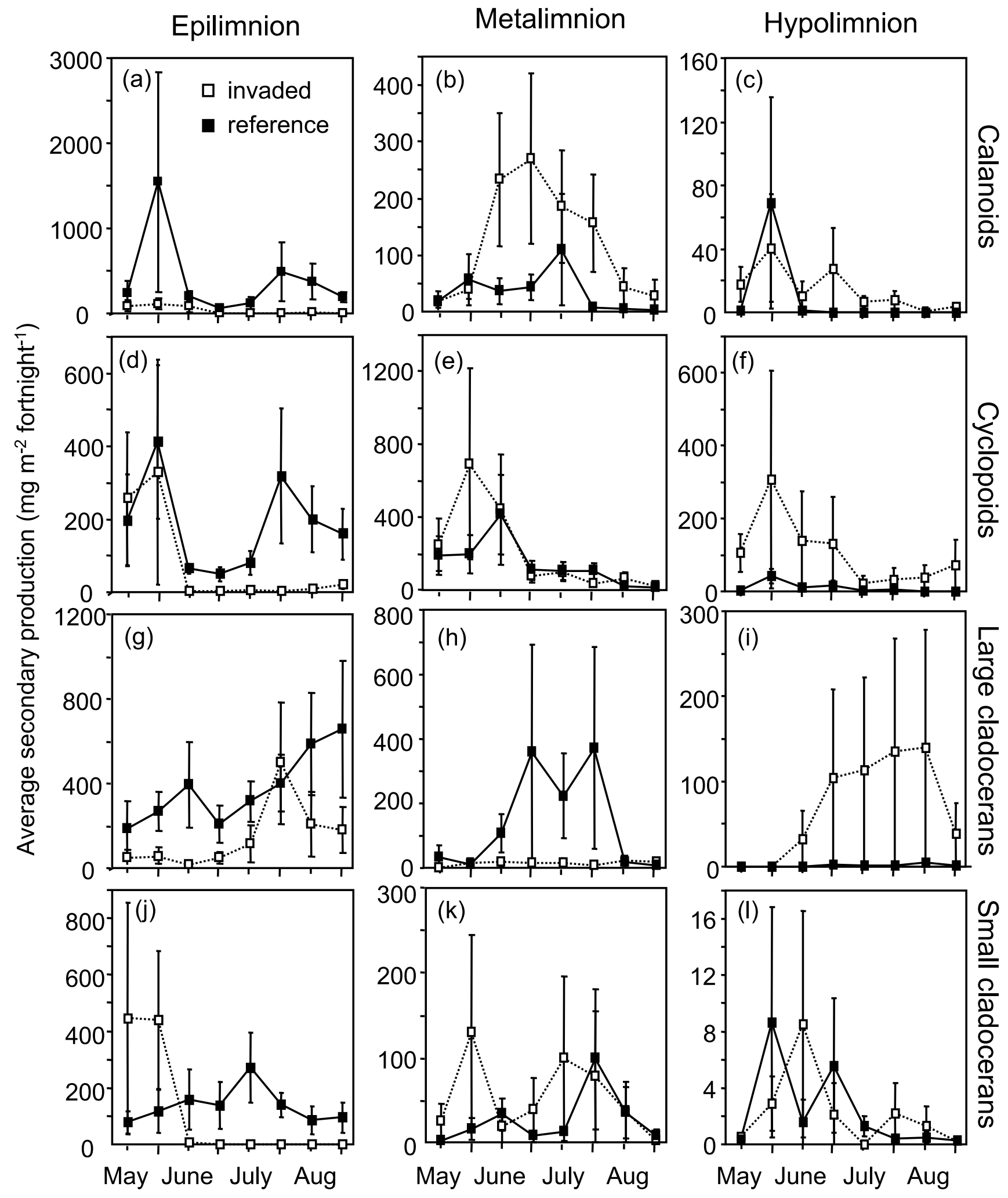

Fig. 3 

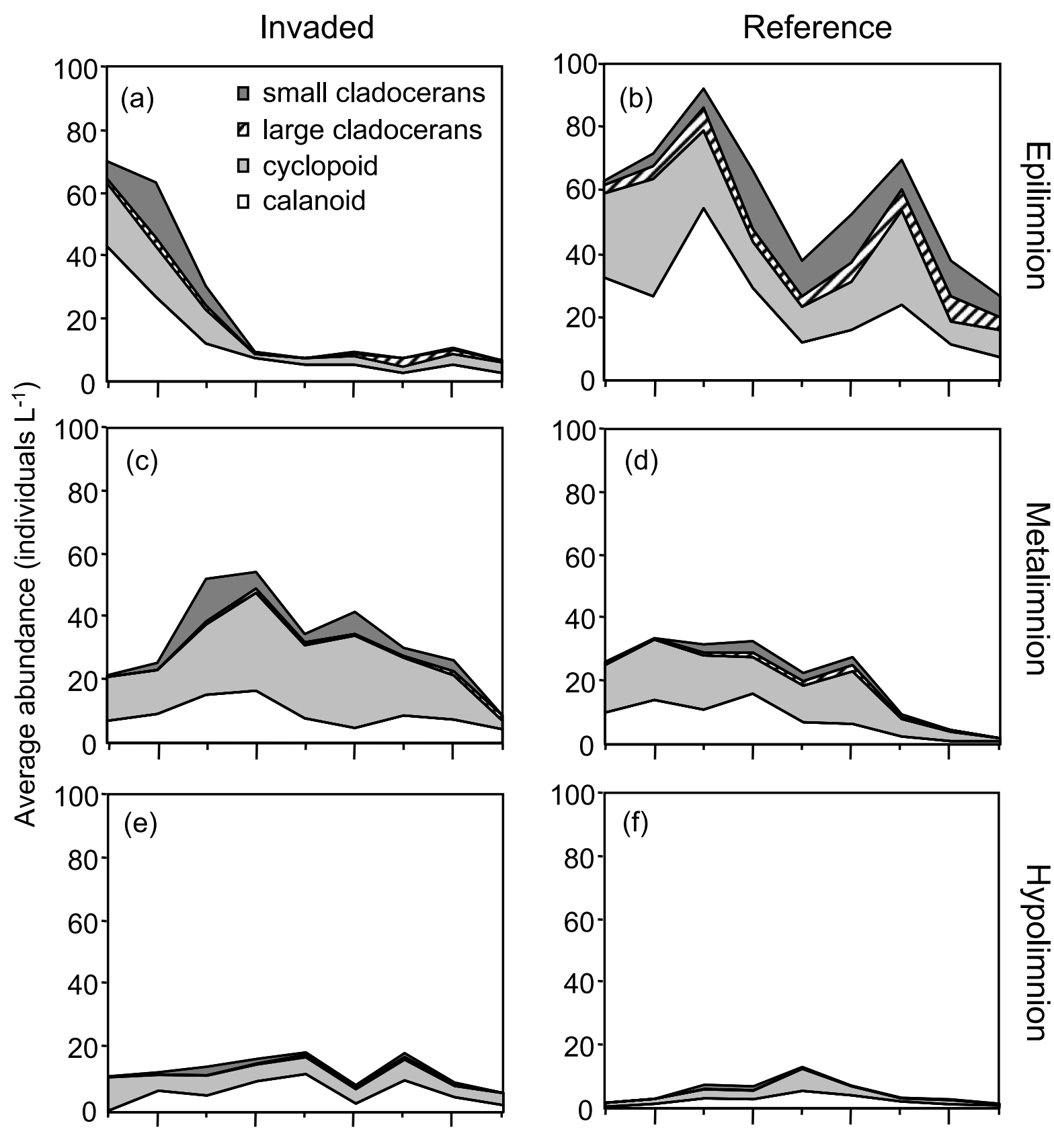

May June July Aug Sept May June July Aug Sept

Fig. 4 


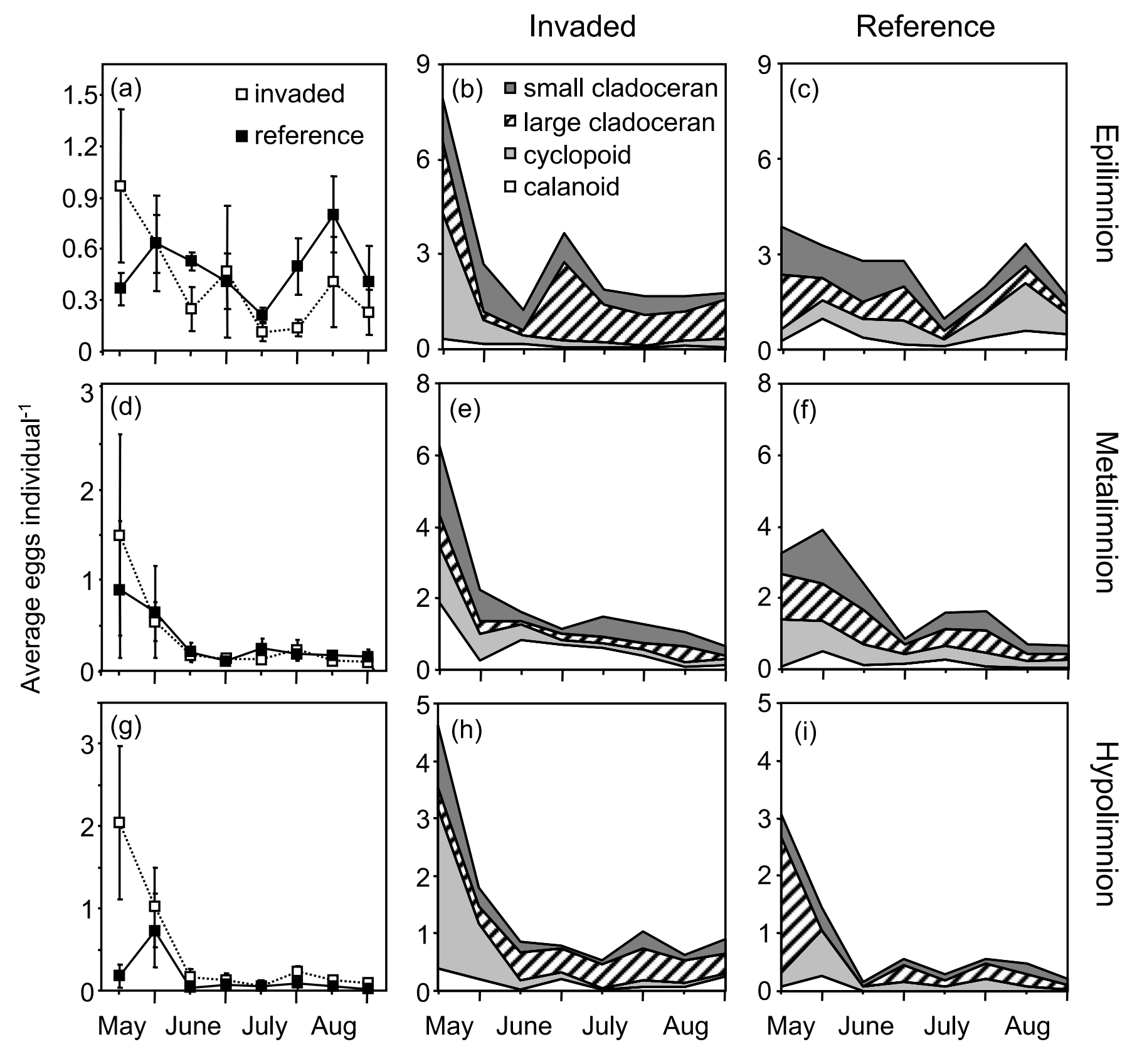

Fig. 5 


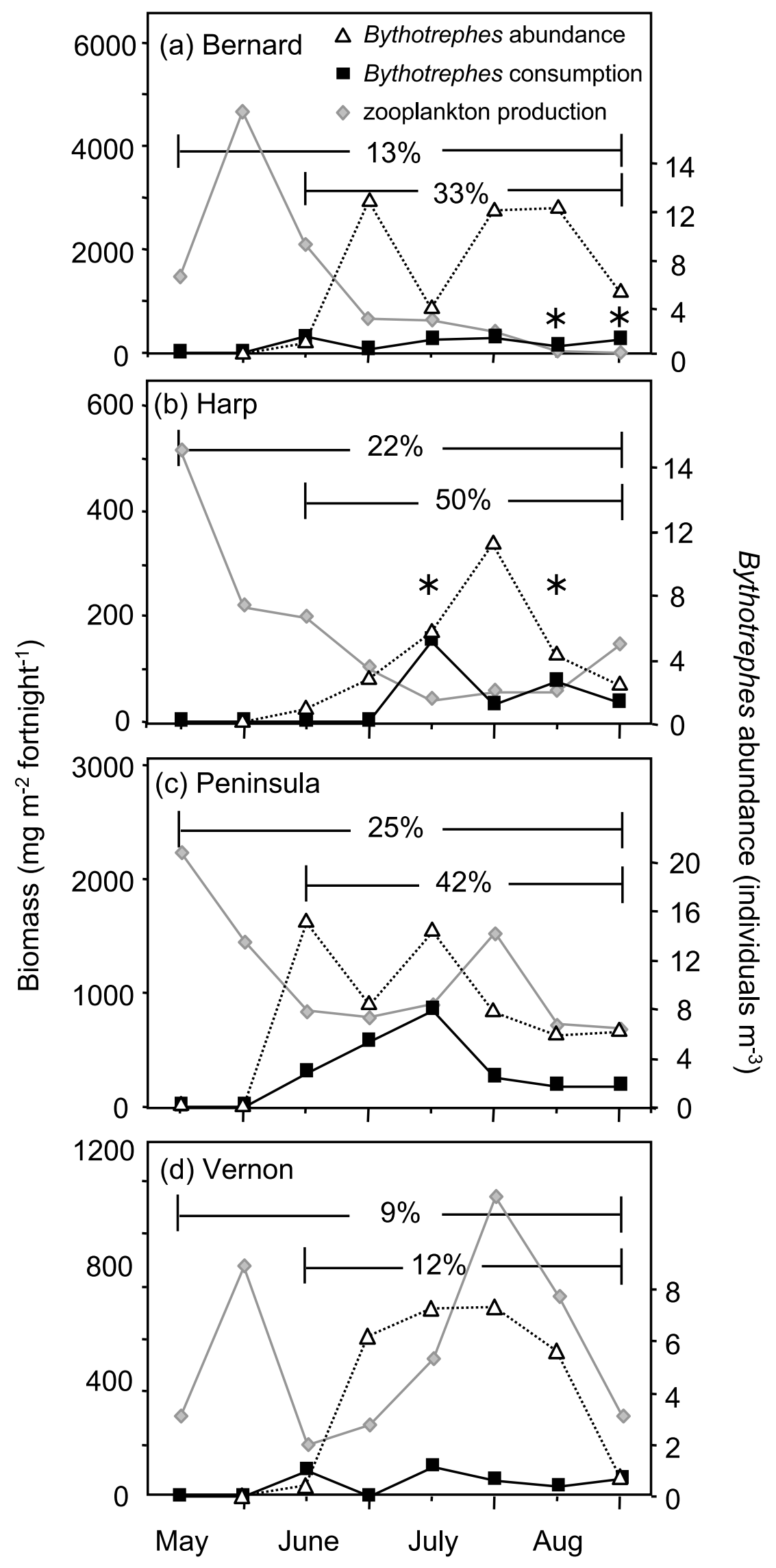

Fig. 6 

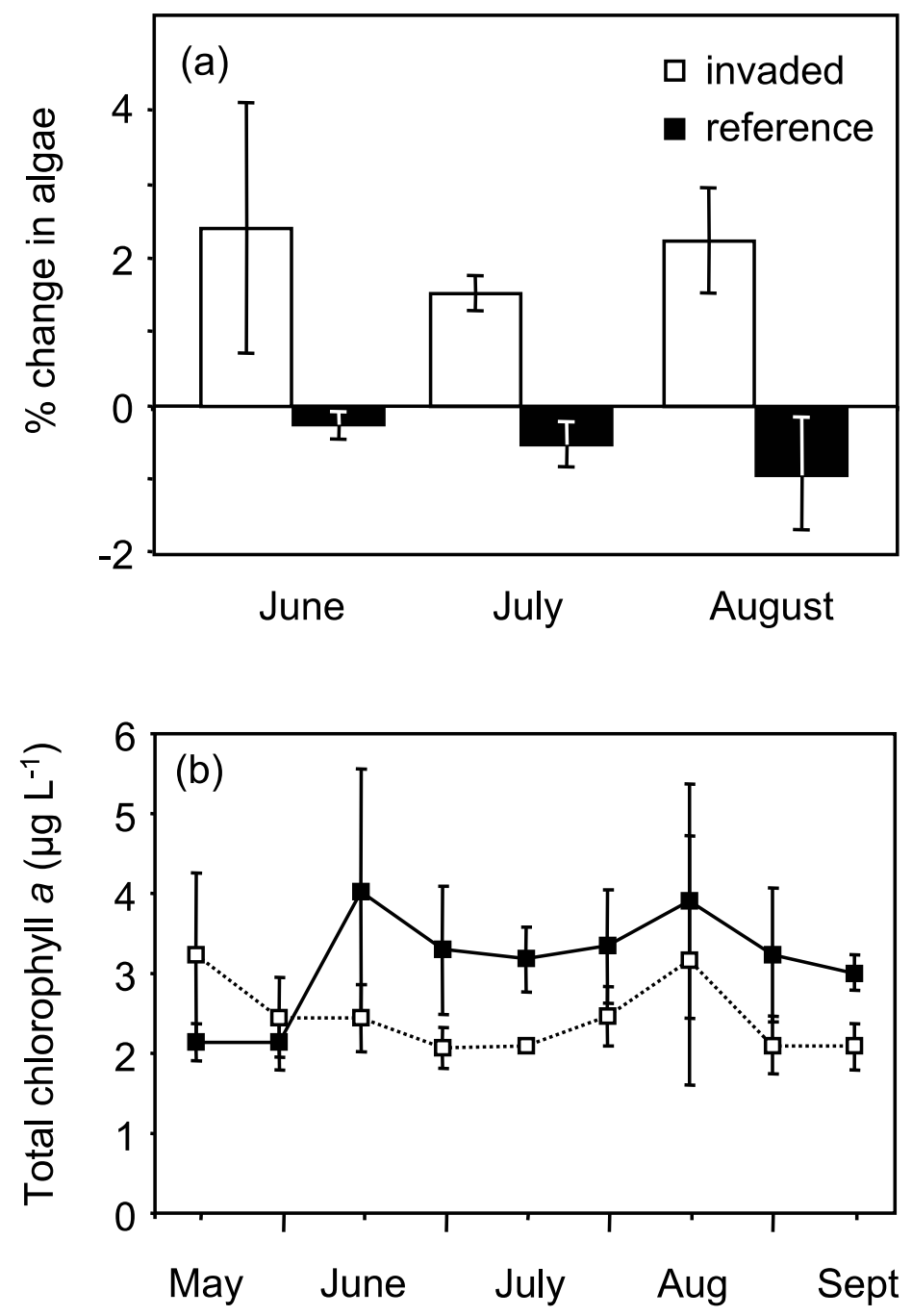

Fig. 7 